Bangladesh J. Sci. Res. 29(1): 11-17, 2016 (June)

\title{
HEAVY METAL CONTENTS IN SOILS AFFECTED BY INDUSTRIAL ACTIVITIES IN A SOUTHERN DISTRICT OF BANGLADESH
}

\author{
Monira Begum and S.M. Imamul Huq ${ }^{*}$ \\ Bangladesh Australia Centre for Environmental Research (BACER-DU), Department of Soil, \\ Water and Environment, University of Dhaka, Dhaka-1000, Bangladesh
}

\begin{abstract}
A research was done to focus on the level of heavy metal pollution by three point sources in Barisal, a southern district of Bangladesh. Soils were collected from four distinct distances (100 m, $200 \mathrm{~m}, 400 \mathrm{~m}$ and $600 \mathrm{~m}$ from the point of discharge) of three different industrial sites, namely textile, cement and medicine industry. Maximum build-up of heavy metals was found in the vicinity of textile industry, while the minimum was observed in soils of medicine industry. $\mathrm{Cu}, \mathrm{Cr}, \mathrm{Cd}, \mathrm{Mn}$ and $\mathrm{Ni}$ were found in the highest concentrations in textile industry, while $\mathrm{As}, \mathrm{Pb}$ and $\mathrm{Zn}$ were found in the highest content near the cement industry. Negative correlation values indicate that pollution levels decrease with the increasing distance from the pollution sites.
\end{abstract}

Key words: Heavy metals, point source, discharge, build-up, pollution level

\section{Introduction}

Environmental contamination and exposure to heavy metals is a serious growing problem throughout the world, as both natural sources and anthropogenic processes emit heavy metals into various environmental media. Although heavy metals are naturally occurring elements that are found in trace amounts throughout the earth's crust in different forms as minerals, in oars, or in rocks, most environmental contamination and human exposure result from anthropogenic activities such as mining and smelting operations, industrial production and use, and domestic and agricultural use of metals and metal-containing compounds (Goyer 2001). Environmental contamination can also occur through metal corrosion, atmospheric deposition, soil erosion of metal ions and leaching of heavy metals, sediment re-suspension and metal evaporation from water resources to soil and ground water (Nriagu 1989). Natural phenomena such as weathering and volcanic eruption have also been reported to significantly contribute to heavy metal pollution (Fergusson 1990 and Bradl 2002). Industrial sources include metal processing in refineries, coal burning in power plants, petroleum combustion, nuclear power stations and high tension lines, plastics, textiles, microelectronics, wood preservation and paper processing plants (Pacyna 1996). Thus, heavy metals are being released into the environment from numerous point and non-point sources. In recent years, there has been a growing concern associated with the environmental contamination by these heavy metals. Also human exposure has been increased dramatically as a result of their increased use in several industrial, agriculture and domestic applications. Therefore, research has been focused on the routes of exposure of the heavy metals, their potential sources,

*Author for correspondence: < imamhuq@hotmail.com>. 
possible pathways through which heavy metals are being transferred into the food chain. The present research focused on the concentrations of some heavy metals in some areas of Barisal which will be helpful to comment that whether heavy metals are being released from some point sources and that might be a cause of potential threat of their build-up in the food chain.

\section{Materials and Methods}

The research area is located in Barisal district of Bangladesh, the district headquarters of a division in the southern part of Bangladesh. There are very few industries in Barisal and therefore the samples were collected in such a manner that it would cover the major industrial areas of Barisal. The soil samples were collected from three different industrial vicinity of Barisal. The three industries chosen are cement, pharmaceutical and textile mills. The geo reference of the sampling sites are 22.6526439” N to 90.3455835” E; 22.7019324” N to 90.3689228” E and 22.6668328” N to 90.3459855 ” E, respectively. Among the three sampling areas soil samples were collected from about 100, 200, 400 and more than $600 \mathrm{~m}$ away from the discharge sites of the industries.

The soil samples representing 0 - $15 \mathrm{~cm}$ depth from the surface were collected by "Composite soil sampling" method as suggested by the Soil Survey Staff of the USDA (1951). The samples were scraped from top to bottom with the help of an auger, mixed together in polythene bags and transported to the laboratory. The collected soil samples were dried in air for about three days. After air-drying larger aggregates were ground by gently crushing with a wooden hammer. Then the ground samples were sieved by passing through a $2 \mathrm{~mm}$ sieve. The sieved samples were then stored in a cool dry place in the laboratory.

For the analysis of the heavy metals the soil samples were extracted with 'Aqua regia' (HCl: $\mathrm{HNO}_{3}=3: 1$ ) digestion mixture as described by Huq and Alam (2005). A reagent blank was also made for maintaining the accuracy. Then the content of total $\mathrm{Pb}, \mathrm{Zn}, \mathrm{Mn}, \mathrm{Ni}, \mathrm{As}, \mathrm{Cu}, \mathrm{Cr}$ and $\mathrm{Cd}$ were analyzed by using a 'Varian Spectra-220' AAS. The quality control/quality assurance (QC/QA) of the analyses was maintained following the standard procedure.

\section{Results and Discussions}

Concentrations of different heavy metals of the collected samples are presented in the Table 1 and in the Figs 1, 2 and 3. For a better understanding the figures are represented in log scale.

Cement industry: Concentrations of $\mathrm{Pb}$ were found to be the maximum close to the cement industry that ranged from 11.6 to $38.5 \mathrm{mg} / \mathrm{kg}$. The maximum concentration was observed in the samples collected at 100 meter distance from the factory which exceeded the typical content of $\mathrm{Pb}$ in soils as suggested by Huq and Alam (2005). The total contents of Pb were found to decrease with increase in distance from the cement industry (Fig. 1). The average value of $\mathrm{Pb}$ found near the cement industry was $23.4 \mathrm{mg} / \mathrm{kg}$ (Table 1). The content of $\mathrm{Zn}$ in the soils collected from the vicinity of cement industry ranged from 78.8 to $151.1 \mathrm{mg} / \mathrm{kg}$ with a mean value of $111.6 \mathrm{mg} / \mathrm{kg}$. The maximum content of $\mathrm{Zn}$ was found at the closest distance $(100 \mathrm{~m})$, while with increase in 
distance its total content decreased (Fig. 1). The highest content of Mn was found near the cement industry which ranged within 136.8 to $495.2 \mathrm{mg} / \mathrm{kg}$ and the average of which was $333.0 \mathrm{mg} / \mathrm{kg}$. Ni concentration was found to be $3.1 \mathrm{mg} / \mathrm{kg}$. This value ranks second among the three industries studied. The sample which was collected from close to the cement industry, i.e. from 100 meter, showed the highest $\mathrm{Ni}$ contamination (Table 1) while it's content decreased with increasing distance (Fig. 1). The concentrations of As in the collected soil samples ranged from 1.4 to 2.5 $\mathrm{mg} / \mathrm{kg}$ while the mean content was $2.1 \mathrm{mg} / \mathrm{kg}$. The concentration varied slightly among the soil samples collected from four different distances as 100, 200, 400 and $600 \mathrm{~m}$ from the cement industry. There is no uniform change in arsenic concentration with increasing distance from the cement industry (Fig. 1). Average concentrations of other heavy metals such as $\mathrm{Cu}, \mathrm{Cr}$ and $\mathrm{Cd}$ in and around the cement factory were $9.4,38.3$ and $0.6 \mathrm{mg} / \mathrm{kg}$.

Table 1. Maximum, minimum and average concentrations $(\mathrm{mg} / \mathrm{kg})$ of heavy metals.

\begin{tabular}{llllllllll}
\hline $\begin{array}{l}\text { Sampling } \\
\text { site }\end{array}$ & Values & $\mathrm{Pb}$ & $\mathrm{Zn}$ & $\mathrm{Mn}$ & $\mathrm{Ni}$ & $\mathrm{As}$ & $\mathrm{Cu}$ & $\mathrm{Cr}$ & $\mathrm{Cd}$ \\
\hline Cement & Min & 11.6 & 78.86 & 136 & 1.59 & 1.45 & 2.7 & 22.05 & 0.5 \\
industry & Max & 38.52 & 151.1 & 495.2 & 3.11 & 2.5 & 15.88 & 55 & 0.77 \\
& Average & 23.39 & 111.6 & 333.02 & 2.29 & 2.13 & 9.36 & 38.26 & 0.62 \\
Textile & Min & 8.2 & 27.91 & 236.4 & 1.31 & 1.364 & 8.92 & 95.1 & 0.9 \\
industry & Max & 33.22 & 67.6 & 590.3 & 4.56 & 1.45 & 36.5 & 185.4 & 3.2 \\
& Average & 18.48 & 49.08 & 451.35 & 3.05 & 1.41 & 25.11 & 132.5 & 1.9 \\
& Min & 10.6 & 35.5 & 66.9 & 1.3 & 1.77 & 2.2 & 15 & 0.5 \\
Medicine & Max & 12.68 & 59.56 & 188.4 & 2.23 & 1.05 & 7.1 & 30 & 0.87 \\
Industry & Average & 11.42 & 46.01 & 114.32 & 1.9 & 1.67 & 3.93 & 25.73 & 0.78 \\
& Typical content & $32 * *$ & $64 * *$ & $437 * *$ & $50^{*}$ & $8 * *$ & $26 * *$ & $65^{* *}$ & $<1^{* *}$ \\
\hline
\end{tabular}

*As suggested by Madejon et al. 2002 and Shallari et al. 1998; ** As suggested by Huq and Alam 2005.

The correlation coefficient (r) of different heavy metals in the industrial sites along with increase in distance is presented in Table 2. The correlation analysis showed that the concentrations of different heavy metals are negatively related with increase in distance.

Cement factory emissions might represent the most important pollution source than the others. Al-Khashman (2006) observed that high concentrations of $\mathrm{Pb}, \mathrm{Zn}, \mathrm{Mn}$ and $\mathrm{Ni}$ may be present in soils close to the cement plant. This could be related due to the fact that the process and production of cement factory require a great amount of energy (supplied by burning of fossil fuel) and also by the traffic activities in and around the plant (Banat et al. 2005).

Textile industry: Textile industries can be a major source of metal pollution in the environment (Deepali and Gangwar 2010). The analysis of the present study showed that concentrations of $\mathrm{Mn}, \mathrm{Ni}, \mathrm{Cu}, \mathrm{Cr}$ and $\mathrm{Cd}$ were in its maximum level in soils collected from around the textile industry (Fig. 2). The content of Mn was $590.3 \mathrm{mg} / \mathrm{kg}$ with an average of $451.3 \mathrm{mg} / \mathrm{kg}$, while the lowest value found was $236.4 \mathrm{mg} / \mathrm{kg}$. Maximum $\mathrm{Ni}$ content was $4.6 \mathrm{mg} / \mathrm{kg}$ with an 
average value of $3.0 \mathrm{mg} / \mathrm{kg}$. Highest value of $\mathrm{Cu}(36.5 \mathrm{mg} / \mathrm{kg})$ was detected in the samples collected from 100 meter distance whereas the lowest value $(8.9 \mathrm{mg} / \mathrm{kg})$ was found in soils collected from beyond 600 meter. The maximum concentrations of other heavy metals such as $\mathrm{Pb}$, $\mathrm{Zn}, \mathrm{As}, \mathrm{Cr}$ and $\mathrm{Cd}$ near the textile industry were 33.2, 67.6, 1.4, 185.4 and $3.2 \mathrm{mg} / \mathrm{kg}$ where the averages of the same were 18.5, 49.1, 1.4, 132.5 and $1.9 \mathrm{mg} / \mathrm{kg}$, respectively. Bergmann (1992) has showed that the critical levels of $\mathrm{Cr}$ in soil were around 2 - $50 \mathrm{mg} / \mathrm{kg}$ and compared to that in the present case the $\mathrm{Cr}$ content in the analyzed soil samples was very high around the textile area. In general, with increasing distance from the industry, the level of trace elements in the soil decreased, which is also proven by the negative values of the correlation coefficient (Table 2).

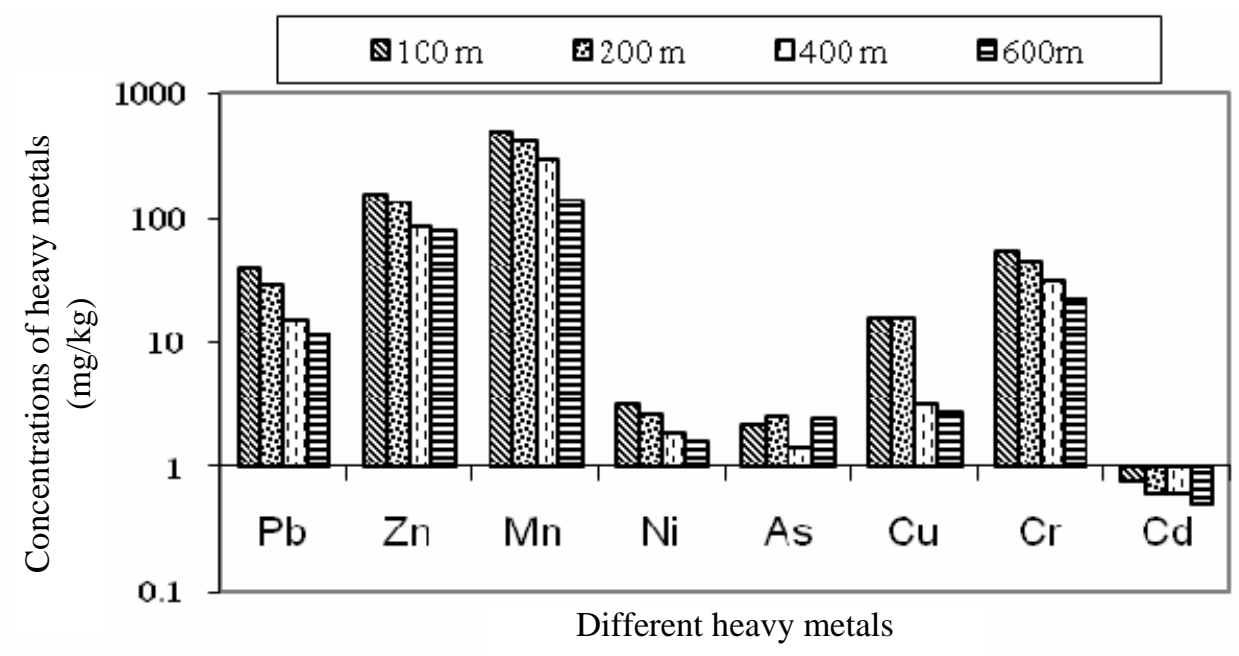

Fig. 1. Concentration of different heavy metals around cement industry.

Table 2. Correlation coefficient ( $r$ ) of different heavy metals in the industrial sites with distance.

\begin{tabular}{lrccccccc}
\hline Soils & $\mathrm{Pb}$ & $\mathrm{Zn}$ & $\mathrm{Mn}$ & $\mathrm{Ni}$ & $\mathrm{As}$ & $\mathrm{Cu}$ & $\mathrm{Cr}$ & $\mathrm{Cd}$ \\
\hline Cement & -0.96 & -0.95 & -0.998 & -0.97 & -0.09 & -0.92 & -0.99 & -0.90 \\
Textile & -0.93 & -0.97 & -0.97 & -0.99 & -0.80 & -0.99 & -0.90 & -0.96 \\
Medicine & -0.91 & -0.92 & -0.90 & -0.97 & 0.40 & -0.84 & -0.91 & -0.90 \\
\hline
\end{tabular}

It was evident that significant amounts of trace metals have been released into the surrounding soils from the textile industry. Similar observations were also made by Kashem and Sing (1999). The reason for the presence of the trace elements in the surrounding soil could be related to the processing of fabrics in textile industry where a number of heavy metals (especially $\mathrm{Cu}, \mathrm{Cr}, \mathrm{Zn}$, etc.) are used in dying and printing steps (Smith 1988). Noor et al. (2015) have observed that most of the textile industries use traditional methods for producing fabrics from 
yarn, releasing untreated toxic effluents that contain dyes, waxes and heavy metals. Textile industry is thus a potential source of the trace metals release and subsequent build-up in the vicinity of it.

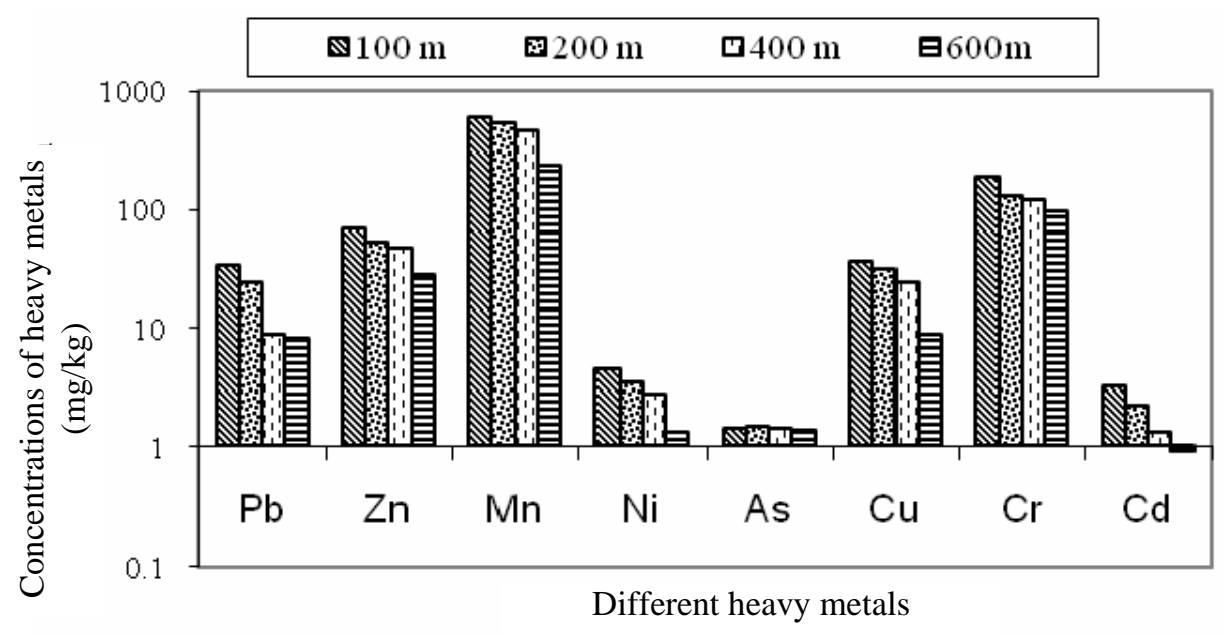

Fig. 2. Concentration of different heavy metals around textile industry.

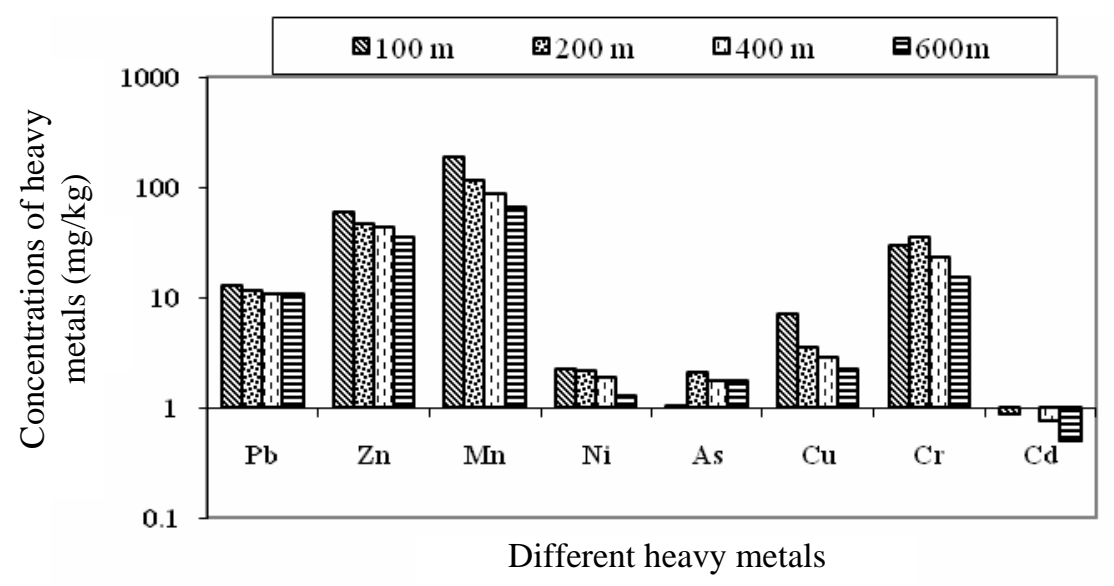

Fig. 3. Concentration of different heavy metals around pharmaceutical industry.

Medicine industry: Pharmaceutical or medicine industry also releases effluents which might increase the heavy metal content of the adjacent soil. In the present study, analysis of the collected soil samples adjacent to the medicine industry showed that, there were different heavy metals. The content of $\mathrm{Pb}, \mathrm{Zn}, \mathrm{Mn}, \mathrm{Ni}, \mathrm{As}, \mathrm{Cu}, \mathrm{Cr}$ and $\mathrm{Cd}$ were analyzed. The maximum values were 12.7 , 59.6, 188.4, 2.2, 1.0, 7.1, 30.0 and $0.9 \mathrm{mg} / \mathrm{kg}$ with averages of 11.4, 46.01, 114.3, 1.9, 1.7, 3.9, 25.7 and $0.8 \mathrm{mg} / \mathrm{kg}$, respectively. Comparing with the typical contents of heavy metals in soil as 
suggested by Huq and Alam (2005) (Table 1), it could be stated that although the average concentrations of these trace metals are below the typical content in soil but as they are present in the soil, they might be concentrated in course of time. Maximum concentration of $\mathrm{Zn}$ was 59.6 $\mathrm{mg} / \mathrm{kg}$ which is close to the typical content (Table 1$)$ and the concentration of Cd obtained (0.87 $\mathrm{mg} / \mathrm{Kg}$ ) is also close to the typical content $(<1 \mathrm{mg} / \mathrm{kg}$ ). It is likely that the concentration might include a build-up in course of time.

Considering the metal concentration levels determined, the overall mean values for different trace metals around the cement industry could be arranged as $\mathrm{Mn}>\mathrm{Zn}>\mathrm{Cr}>\mathrm{Pb}>\mathrm{Cu}>\mathrm{Ni}>\mathrm{As}$ $>\mathrm{Cd}$, for the textile industry as $\mathrm{Mn}>\mathrm{Cr}>\mathrm{Zn}>\mathrm{Cu}>\mathrm{Pb}>\mathrm{Ni}>\mathrm{Cd}>$ As and for the medicine industry the sequence followed a similar trend $\mathrm{Mn}>\mathrm{Zn}>\mathrm{Cr}>\mathrm{Pb}>\mathrm{Cu}>\mathrm{Ni}>\mathrm{As}>\mathrm{Cd}$.

It is apparent from the present study that build up of heavy toxic trace metals is evident around industrial belts. Efficient and proper effluent treatments are prerequisites for such industries to avoid further build up of these heavy metals.

\section{References}

Al-Khashman, O.A. and R.A. Shawabkeh. 2006. Metals distribution in soils around the cement factory in southern Jordan. Environ. Poll. 140(3): 387-394.

Banat, K.M., F.M. Howari and A.A. Al-Hamad. 2005. Heavy metals in urban soils of central Jordan: Should we worry about their environmental risks? Environ. Research 97(3): 258-273.

Bergmann, W. 1992. Nutritional disorders of plants, Gustav Fisher, New York.

Bradl, H. 2002. Heavy Metals in the Environment: Origin, Interaction and Remidiation. Vol. 6. London: Academic Press.

Deepali, K.K. and K. Gangwar. 2010. Metals concentration in textile and tannery effluents, associated soils and ground water. New York Science J. 3(4): 82-89.

Fergusson, J.E. 1990. The Heavy Elements: Chemistry, Environmental Impact and Health Effects. Oxford: Pergamon Press.

Goyer, R.A. 2001. Toxic effects of metals. In: Toxicology: The Basic Science of Poisons. C. D. Klaassen (ed), New York: McGraw-Hill Publisher.

Huq, S.M.I. and M.D. Alam. 2005. A Handbook on Analysis of Soil, Plant and Water. Bangladesh-Australia Centre for Environmental Research (BACER-DU), University of Dhaka, Dhaka-1000.

Kashem, A. and B. R. Singh. 1999. Heavy metal contamination of soil and vegetation in the vicinity of industries in Bangladesh. Water, Air and Soil Poll. 115(1-4): 347-361.

Madejon, P., J.M. Murillo, T. Maranon, F. Cabrera and R. Lopez. 2002. Bioaccumulation of As, Cd, Cu, Fe and $\mathrm{Pb}$ in wild grasses affected by the Aznalcollar mine spill. Sci. Total Environ. 309:105-120.

Noor, S., M.N.Z. Muslim, and H. Rohasliney. 2015. Determination of heavy metal contamination from batik factory effluents to the surrounding area. International J. Chemical, Environ. \& Biol. Sci. 3(1):7-9.

Nriagu, J.O. 1989. A global assessment of natural sources of atmospheric trace metals. Nature 338: 47-49.

Pacyna, J.M. 1996. Monitoring and assessment of metal contaminations in the air. In: Chang, L. W., L. Magos, T. Suzuli, (edi). Toxicology of Metals. CRC Press.

Shallari, S., C. Schwartz, A. Hasko and J.L. Morel. 1998. Heavy metals in soils and plants of serpentine and industrial sites of Albania. Sci. Total Environ. 209: 133-142. 
Heavy metal contents in soils affected by industrial activities

Smith, B.A. 1988. A Workbook for Pollution Prevention by Source Reduction in Textile Wet Processing. Pollution Prevention Pays Program of the North Carolina Division of Environmental Management.

USDA (United States Department of Agriculture). 1951. Soil Survey Manual by Soil Survey Staff. Bureau of Plant Industry, Soil and Agricultural Engineering. Handbook No. 18: 205. US Govt. Printing Office, Washington, DC.

(Manuscript received on 26 June, 2016; revised on 21 July, 2016) 